Article

\title{
Gerakan Mahasiswa Sebagai Agen Perubahan Sosial di Kabupaten Bungo
}

\author{
Joko Setyoko ${ }^{1 *}$, Muhammad Deby Satria ${ }^{2}$
}

This article is an open access article distributed under the terms and conditions of the Creative Commons Attribution-ShareAlike 4.0 International (CC BY SA ) License (https://creativecommo ns.org/licenses/bysa $/ 4.0 /$ ).

\section{Jurnal Politik dan} Pemerintahan Daerah ISSN 2686-2271

Fakultas Ilmu Sosial dan Ilmu Politik, Universitas Muara Bungo Jl. Diponegoro No. 27, Muara Bungo-Jambi, (0747) 323310

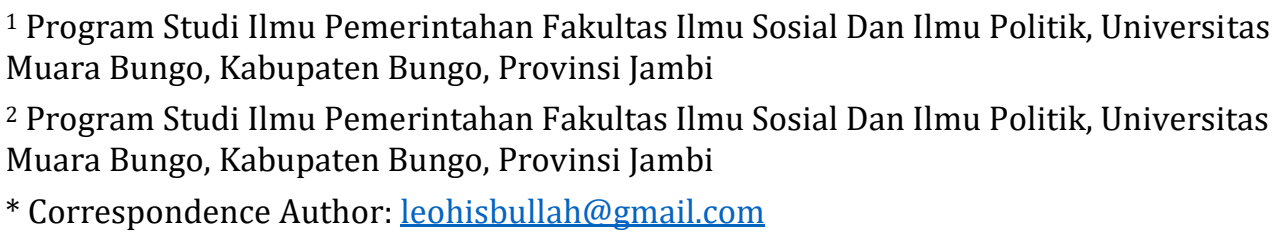

${ }^{1}$ Program Studi Ilmu Pemerintahan Fakultas Ilmu Sosial Dan Ilmu Politik, Universitas Muara Bungo, Kabupaten Bungo, Provinsi Jambi

2 Program Studi Ilmu Pemerintahan Fakultas Ilmu Sosial Dan Ilmu Politik, Universitas Muara Bungo, Kabupaten Bungo, Provinsi Jambi

* Correspondence Author: leohisbullah@gmail.com

Abstract: The purpose of this study was to find out how the student movement as an agent of social change in Bungo Regency in advocating student demands, and knowing the obstacles in the student movement as agents of social change in Bungo Regency in advocating student demands. The method used in this research is a qualitative research method with a descriptive study. The method used in this research is a qualitative research method with a descriptive study. The informant selection technique used by the researcher in this study was to use the purposive sampling method (sampling technique with certain considerations). The results of this study indicate that the student movement as agents of social change in Bungo Regency in advocating student demands is carried out by: Mapping Issues, Pre-Action, Action, and Post-Action. Several obstacles in the student movement as agents of social change in Bungo Regency in advocating student demands, namely: Lack of awareness of students themselves, Globalization and Modernization

Keywords: student movement, agent of change, advocacy;

Abstrak: Tujuan penelitian ini adalah untuk mengetahui bagaimana gerakan mahasiswa sebagai agen perubahan sosial di Kabupaten Bungo dalam advokasi tuntutan mahasiswa, dan mengetahui hambatan dalam pergerakan mahasiswa sebagai agen perubahan sosial di Kabupaten Bungo pada advokasi tuntutan mahasiswa. Metode yang digunakan dalam penelitian ini penelitian ini adalah metode penelitian kualitatif yang bersifat dengan studi deskriptif. Metode yang digunakan dalam penelitian ini penelitian ini adalah metode penelitian kualitatif yang bersifat dengan studi deskriptif. Teknik pemilihan informan yang digunakan oleh peneliti dalam penelitian ini adalah dengan menggunakan metode purposive sampling (teknik penentuan sampel dengan pertimbangan tertentu). Hasil penelitian ini menunjukkan bahwa Gerakan mahasiswa sebagai agen perubahan sosial di Kabupaten Bungo dalam advokasi tuntutan mahasiswa dilakukan dengan: Pemetaan Isu, Pra Aksi, Aksi, dan Pasca Aksi. Beberapa hambatan dalam pergerakan mahasiswa sebagai agen perubahan sosial di Kabupaten Bungo pada advokasi tuntutan mahasiswa yaitu: Kurangnya rasa kesadaran mahasiswa itu sendiri, Globalisasi dan Modernisasi

Kata Kunci: gerakan mahasiswa, agen perubahan, advokasi 


\section{Pendahuluan}

Mahasiswa adalah kelompok sosial masyarakat yang mempunyai kapasitas intelektual untuk memahami kondisi dalam kehidupan bermasyarakat, berbangsa dan bernegara. Mahasiswa juga merupakan agent of change atau agen perubahan yang berperan penting dalam perubahan di masyarakat menuju lebih baik (Istichomaharani \& Habibah, 2016). Selain itu, mahasiswa di era global ini juga menjadi panutan dalam kehidupan masyarakat yang perbuatannya, tindak tanduknya berlandaskan pada pengetahuan dan norma-norma dalam kehidupan (Cahyono, 2019). Hal ini terjadi karena mahasiswa merupakan orang-orang yang mempunyai kesempatan lebih untuk mengenyam pendidikan, sehingga kemampuan berpikir kritis banyak dimiliki oleh kalangan ini. Sikap kritis dalam diri mahasiswa tidak terlepas dari kondisi negara serta pemerintah yang sedang berkuasa, keresahan sosial serta dampak dari kebijakan pemerintah akan menjadi sorotan mahasiswa. Keresahan sosial yang dimaksud biasanya berawal dari kesejahteraan rakyat, ketika kesejahteraan belum tercapai maka sikap kritis mahasiswa akan selalu berbuah pergerakan mahasiswa, disinilah pemerintah dituntut untuk mampu mengakomodir aspirasi mahasiswa, karena aspirasi yang tidak tertampung biasanya mengakibatkan tindakan yang anarkis dari aksi demonstrasi mahasiswa.

Indonesia adalah Negara demokrasi yang berlandaskan pancasila dan Undang-Undang Dasar. Dimana di negeri ini setiap orang berhak untuk bersuara dan mengemukakan pendapat. Menurut Georg Sorensen, demokrasi secara sederhana merupakan metode politik, sebuah mekanisme untuk memilih pemimpin politik (George Sorensen, 2003). Ketika terdapat kesenjangan antara peraturan dan situasi yang terjadi dilapangan mahasiswa berhak untuk memprotes dan menyampaikan aspirasinya karena Negara yang demokratis akan mengakomodir gerakan mahasiswa menjadi salah satu aspirasi rakyat karena mahasiswa merupakan salah satu komponen rakyat. Gerakan mahasiswa di Indonesia adalah kegiatan kemahasiswaan di dalam maupun di luar perguruan tinggi yang dilakukan untuk meningkatkan kecakapan, intelektualitas dan kemampuan kepemimpinan para mahasiswa yang terlibat di dalamnya. Gerakan mahasiswa merupakan suatu sikap yang terhimpun dalam organisasi. Organisasi ini terdiri dari mahasiswa yang terdaftar sebagai anggota di dalamnya. Pengingkatan perolehan prestasi akademik mahasiswa dapat dipengaruhi oleh faktor eksternal yang berupa partisipasi mahasiswa dalam kegiatan di lingkungan sekitarnya (Kurniawati \& Leonardi, 2013).

Gerakan mahasiswa biasanya berupa sikap mengkritik atau menolak yang direpresentasikan dalam bentuk tulisan ataupun aksi demonstrasi melalui wadah organisasi terhadap kebijakan pemerintah. Seperti aksi yang dilakukan oleh gerakan mahasiswa dari semua perguruan tinggi dikabupaten Bungo yang dimulai sekitar pukul 11:00 WIB pada tanggal 26 September 2019 yang dihadiri oleh ratusan mahasiswa. Aksi tersebut hampir saja sempat diwarnai kericuhan akibat mahasiswa berusaha masuk ke gedung DPRD Bungo tetapi dihalangi oleh aparat keamaan. Ban bekas pun turut dibakar mahasiswa sembari menyanyikan lagu "Indonesia raya dan disusul dengan lagu darah juang" sebagai bentuk kekecewaan terhadap kebijakan Dewan Perwakilan Rakyat Daerah (DPRD) dalam membuat kebijakan. Aliansi mahasiswa se-kabupaten Bungo melihat bahwasannya kebijakan yang dibuat oleh Dewan Perwakilan Rakyat Daerah (DPRD) tidak berjalan dengan baik, sehingga masyarakat menilai kinerja Dewan Perwakilan Rakyat Daerah (DPRD) dianggap tidak pro rakyat, dan pada aksi ini mahasiswa juga mengajukan beberapa tuntutan yang bertolak belakang dengan kehidupan sosial dan hak-hak masyarakat. Berikut beberapa tuntutan yang diajukan oleh mahasiswa terhadap Dewan Perwakilan Rakyat Daerah (DPRD) tentang persoalan daerah, diantaranya: 
1. Lingkungan Pencemaran lingkungan, seperti di Sungai Batang Bungo dan Sungai Batang Tebo.

\section{Perda}

- Penegasan tentang hewan ternak yang banyak berkeliaran.

- Hiburan malam yang berkedok perjudian.

- Mempertanyakan devisit anggaran dan infra struktur gagal fungsi.

- Penertiban pedagang kaki lima yang memakan trotoar bagi pejalan kaki.

- kontrak 100 hari kerja seluruh anggota DPRD Bungo.

- DPRD harus melakukan diskusi bersama mahasiswa per 3 bulan sekali kerja.

Gerakan mahasiswa sebagai agen kontrol sosial, diibaratkan seperti sebuah lonceng besar yang setiap waktu dapat berbunyi dengan sangat keras untuk mengingatkan dan menyadarkan pihak lain ketika mereka sedang lupa diri. Mereka harus terus memantau setiap proses perubahan yang sedang berjalan, agar arah dan tujuan perubahan yang dicita-citakan tidak melenceng dari tujuan awal.

Dalam posisinya sebagai agen kontrol sosial, mahasiswa harus bertindak objektif, logis, rasional, dan berfikir secara intelektual agar dapat melakukan justifikasi obyektif terhadap setiap persoalan yang terjadi dengan mengambil posisi penengah/pengontrol situasi dan keinginan masyarakat, aktivitas pergerakan mahasiswa dilihat pula sebagai salah satu ukuran kepuasan masyarakat. Mahasiswa yang mengambil posisi kontrol sosial tentu saja harus mempunyai konsensus bersama guna memahami masyarakat melalui kajian-kajian intern tiap organisasi pergerakan mengenai format Indonesia masa depan untuk kemudian menggiring ke arah tersebut.

Format ini akan menjadi semacam visi besar mahasiswa yang harus ditegaskan kepada seluruh pelaku politik. Dalam mainframe inilah mahasiswa dapat menjalankan fungsinya sebagai kontrol sosialnya dengan menggunakan mass power dan institusional power yang dimilikinya. Kontrol sosial yang dilakukan yakni berkaitan dengan segala hal yang terjadi di Indonesia, terutama yang berhubungan tentang tindakan atau kebijakan yang diterapkan pemerintah dalam mewujudkan cita-cita bangsa dan negara

Tuntutan lain yang diajukan oleh mahasiswa Kabupaten Bungo adalah tentang kinerja para wakil rakyat dilingkungan wilayah kabupaten bungo yang dianggap belum maksimal. Sehingga banyak keluhan yang muncul dari bebagai kalangan khususnya di daerah Kabupaten Bungo.

Mahasiswa kabupaten Bungo mengajukan tuntutan melalui kontrak politik untuk memastikan 100 hari kerja kepada seluruh anggota Dewan Perwakilan Rakyat Daerah (DPRD), hal ini dipergunakan oleh mahasiswa sebagai acuan untuk memonitoring kinerja Dewan Perwakilan Rakyat Daerah (DPRD) terhadap perkembangan tuntutan yang telah diajukan oleh mahasiswa agar terealisasikan dalam waktu yang telah disepakati. Dan oleh sebab itu mahasiswa harus benarbenar berada diposisi yang tepat untuk menjamin dan memastikan bahwa tuntutan yang telah diajukan terealisasikan sesuai dengan apa yang diinginkan. Adapun tuntutan mahasiswa terhadap isu-isu lokal di Kabupaten Bungo antara lain:

1. Akan segera membentuk Pansus penyelesaian polemik perizinan lokasi stok file batu bara PT KBPC yang saat ini tepat berada di dalam kota Muara Bungo karena diduga bertentangan dengan undang-undang nomor 20 tahun 2019 tentang perlindungan dan pengelolaan lingkungan hidup.

2. Segera melakukan koordinasi supervisi dengan pemerintah daerah untuk melaksanakan inventarisasi revisi peraturan peraturan daerah yang tidak lagi relevan dengan kondisi sosial ekonomi geografis pertumbuhan penduduk 
kesempatan kerja pendidikan infrastruktur rencana detail tata ruang wilayah sumber daya alam, SDM iklim investasi di Kabupaten hari ini, dengan tujuan dapat memaksimalkan pendapatan daerah dalam kurung untuk kesejahteraan masyarakat dan pembangunan SDM Kabupaten Bungo.

3. Membentuk Pansus untuk melakukan penyelidikan dugaan kebocoran anggaran serta penyebab Realisasi Pendapatan asli daerah tidak mencapai target semu sehingga menjadi sumber defisit APBD Kabupaten Bungo.

4. segera melakukan koordinasi dan supervisi dengan komisi pemberantasan korupsi RI terkait evaluasi Peraturan Bupati Bungo Nomor 10 tahun 2019 tentang pemberian tambahan penghasilan kepada pegawai negeri sipil di lingkungan Pemerintah Kabupaten Bungo yang diduga perhitungannya tidak berdasarkan beban kerja dan resiko kerja melainkan berdasarkan eselonisir.

5. Melakukan evaluasi evaluasi nota pengantar rapbd tahun 2019 yang benarbenar realistis sesuai kemampuan anggaran daerah dengan mempertimbangkan asumsi pendapatan daerah.

6. melakukan evaluasi realisasi APBD setiap opd setiap per triwulan sehingga fungsi pengawasan legislatif dapat optimal dengan tujuan Renstra dapat tetap tetap tepat sasaran.

7. merumuskan formulasi kerjasama dengan pihak perusahaan dalam peluang dan kesempatan kerja melalui dana corporate social responsibility (CSR) yang berada dalam wilayah Bungo.

8. melakukan pendataan dan perhitungan aset aset daerah yang digunakan oleh pihak ketiga dan terhutang sewa melakukan audit dan menghentikan penyertaan modal daerah kepada BUMD yang tidak efektif dan tidak menguntungkan.

9. memberikan ruang diskusi dan evaluasi setiap 3 bulan sekali dalam 1 tahun kepada mahasiswa untuk bersama-sama merumuskan dan memecahkan persoalan yang menjadi kendala dalam pembangunan infrastruktur SDM lapangan kerja dan hal-hal strategis lainnya.

10. melakukan inventarisasi dan penataan ulang seluruh luasan perusahaan perkebunan yang ada dalam kabupaten Bungo iklim investasi di kabupaten hari ini koma dengan tujuan dapat memaksimalkan pendapatan daerah.

11. menyatakan sikap dan berjanji atas nama Allah SWT dan masyarakat Kabupaten Bungo untuk tidak terlibat dalam permainan proyek mengatur proyek menerima fee proyek baik menggunakan nama sendiri maupun atas nama orang lain. Jika dalam 100 hari kerja terhitung sejak hari ini Jumat 30 Agustus 2019 tidak terlaksana maka kami 35 orang anggota DPRD kabupaten Bungo periode 2019-2024 menyatakan secara sadar dan ikhlas mengundurkan diri dari jabatan anggota DPRD kabupaten Bungo periode 2019-2024.

Berdasarkan uraian tersebut, maka peneliti tertarik untuk melakukan penelitian dengan judul "Gerakan Mahasiswa Sebagai Agen Perubahan Sosial di Kabupaten Bungo (Studi Kasus Advokasi Mahasiswa Terhadap Isu-Isu Lokal di Kabupaten Bungo)"

\section{Pembahasan}

Gerakan Mahasiswa Sebagai Agen Perubahan Sosial di Kabupaten Bungo dalam Advokasi Tuntutan Mahasiswa terhadap Isu-isu Lokal di Kabupaten Bungo

Fenomena gerakan sosial dewasa ini cukup dinamis, terlihat dari kemunculan mereka yang, baik sudah terlembaga dengan baik maupun yang bersifat sporadis. Namun, terpenting adalah bahwa gerakan sosial membawa misi tertentu, yakni 
adanya perubahan di dalam masyarakat yang lebih baik dan tentunya demokratis. Tak jarang, mereka justru menjadi pionir bagi perubahan yang bersifat radikal dan fundamental. Mereka berjalan dalam sebuah tuntutan perubahan terhadap kondisi yang dinilai buruk dan sewenang-wenang. Salah satu gerakan sosial yang paling dikenal adalah gerakan mahasiswa. Mereka menjadi bagian penting di dalam mengkerangkai tatanan sosial politik di banyak negara, termasuk Indonesia. Reformasi yang terjadi pada 1998 merupakan buah karya dari gerakan mahasiswa yang menginginkan terjadinya demokratisasi secara benar.

\section{Pemetaan Isu Gerakan Mahasiswa se-Kabupaten Bungo}

Indonesia saat ini sedang dihadapi dengan problematika yang sangat rumit di segala bidang baik dalam bidang ekonomi, pendidikan, sosial, moral dsb. Misalnya dalam bidang ekonomi seperti masih tingginya angka kemiskinan, korupsi merajalela, dilanjutkan lagi dalam bidang pendidikan seperti pendidikan yang tidak merata, banyaknya tawuran antar pelajar, dan pada bidang sosial seperti perang saudara, kriminalitas, dan lain-lain.

Mahasiswa lah yang menjadi bibit-bibit pejuang selanjutnya yang menjadi Agen of Change di segala bidang dan menjadi Social Control yang akan terus menjunjung tinggi keterbukaan dan transparansi dalam melaksanakan pemerintahan agar lebih mensejahterakan rakyatnya dan meminimalisir tingkat penyelewengan di tingkat aparatur negara.

Penelitian ini dimaksudkan untuk memberikan sedikit kontribusi terhadap upaya untuk merevitalisasi peran mahasiswa sebagai Agen of Change dan Social Control. Revitalisasi disini maksudnya adalah proses dan bagaimana cara kita mengoptimalkan kembali peran mahasiswa tersebut, dimana kita ketahui bahwa peran tersebut sedikit demi sedikit mengalami degradasi jika dibandingkan dengan mahasiswa pada zaman sebelum dan awal kemerdekaan, diawal kemerdekaan mahasiswa menjadi penggerak perubahan yang semula Indonesia menjadi negara jajahan banyak negara hingga menjadi negara merdeka hingga saat ini. Dan pada masa awal kemerdekaan dan orde baru menjadi Social Control bagi pemerintah yang tidak transparansi dan tidak adil dalam memegang amanah rakyat.

Advokasi atau dalam bahasa Internasional (Inggris) dikenal dengan sebutan advocacy adalah suatu bentuk tindakan yang menjurus pada pembelaan, dukungan, atau suatu bentuk rekomendasi, yaitu dukungan aktif. Pada tingkat mahasiswa, advokasi biasa dikenal sebagai salah satu departemen dari BEM yang bertugas menjaring aspirasi mahasiswa dan memperjuangkan hak-hak mahasiswa yang belum terpenuhi. Bagi sebagian orang yang telah berkecimpung dalam dunia advokasi, tentu mereka tidak akan menanyakan kembali mengapa mereka melakukan hal itu. Namun, bagi sebagian lainnya yang belum begitu memahami, atau bahkan belum pernah mengenal selukbeluk advokasi, jawaban atas pertanyaan "Mengapa beradvokasi?" menjadi cukup relevan dan urgen untuk dijawab.

Tujuan dari advokasi adalah untuk mendorong terwujudnya perubahan atas sebuah kondisi yang tidak atau belum ideal sesuai dengan yang diharapkan khususnya kebijkan publik. Hal ini dapat dipahami mengapa kebijakan publik menjadi sasaran utama advokasi, karena kebijakan publik merupakan beberapa regulasi yang dibuat berdasarkan kompromi para penguasa (eksekutif, legislatif, dan yudikatif) dengan mewajibkan warganya untuk mematuhi peraturan yang telah dibuat. Setiap kebijakan yang akan disahkan untuk menjadi peraturan perlu dan harus dikawal serta diawasi agar kebijakan tersebut tidak menimbulkan dampak negatif bagi warganya. Hal ini dikarenakan pemerintah ataupun penguasa tidak mungkin mewakili secara 
luas, sementara kekuasaannya cenderung sentralistik dan mereka selalu memainkan peranan dalam proses kebijakan.

Isu adalah langkah awal sebelum melakukan aksi atau propaganda, dan juga dapat dikatakan bahwa kehadiran isu harus menjadi syarat utama dalam pengadvokasian sebuah peristiwa. Isu pun harus menjadi makanan utama bagi seluruh mahasiswa, karena hal tersebut akan menjadi acuan pada kemudian hari untuk bangsa indonesia yang lebih baik. Jika aksi adalah hal terakhir yang dapat dilakukan oleh mahasiswa maka pengakatan isu adalah hal pertama yang harus dilakukan untuk mengubah Indonesia.

Selain tiga isu utama tersebut ada beberapa isu lokal yang diangkat sebagai tuntutan mahasiswa Kabupaten Bungo diungkapkan oleh Junaidi selaku DPM STKIP Muhammadiyah Muara Bungo lain adalah: (Junaidi, Wawancara, 15 April 2020)

1. Polemik perizinan lokasi stok file batu bara PT KBPC yang saat ini tepat berada di dalam kota Muara Bungo karena diduga bertentangan dengan undang-undang.

2. Peraturan peraturan daerah yang tidak lagi relevan dengan kondisi sosial ekonomi geografis pertumbuhan penduduk kesempatan kerja pendidikan infrastruktur rencana detail tata ruang wilayah sumber daya alam, SDM iklim investasi di Kabupaten hari ini, agar dapat memaksimalkan pendapatan daerah untuk kesejahteraan masyarakat dan pembangunan SDM Kabupaten Bungo.

3. Dugaan kebocoran anggaran serta penyebab Realisasi Pendapatan asli daerah tidak mencapai target semu sehingga menjadi sumber defisit APBD Kabupaten Bungo.

4. Pemberian tambahan penghasilan kepada pegawai negeri sipil di lingkungan Pemerintah Kabupaten Bungo yang diduga perhitungannya tidak berdasarkan beban kerja dan resiko kerja melainkan berdasarkan eselonisir.

5. RAPBD tahun 2019 yang tidak realistis sesuai kemampuan anggaran daerah tanpa mempertimbangkan asumsi pendapatan daerah.

6. Kurangnya pengawasan realisasi APBD setiap OPD dikarena lemahnya fungsi pengawasan legislatif.

7. Kurangnya kerjasama dengan pihak perusahaan dalam peluang dan kesempatan kerja melalui dana corporate social responsibility (CSR) yang berada dalam wilayah Bungo.

8. aset aset daerah yang digunakan oleh pihak ketiga tidak diiventarisasi dan terhutang sewa, kurangnya audit dan borosnya penyertaan modal daerah kepada BUMD yang tidak efektif dan tidak menguntungkan.

9. Kurangnya diskusi dan evaluasi DPRD Kabupaten Bungo kepada mahasiswa untuk bersama-sama merumuskan dan memecahkan persoalan yang menjadi kendala dalam pembangunan infrastruktur SDM lapangan kerja dan hal-hal strategis lainnya.

10. Belum dilakukanya inventarisasi dan penataan ulang seluruh luasan perusahaan perkebunan yang ada dalam kabupaten Bungo iklim investasi di kabupaten hari ini, dengan tujuan dapat memaksimalkan pendapatan daerah.

11. Banyaknya anggota DPRD Kabupaten Bungo yang terlibat dalam permainan proyek mengatur proyek menerima fee proyek baik menggunakan nama sendiri maupun atas nama orang lain. 
Dari 11 tuntutan mahasiswa tersebut ada beberapa isu yang menjadi fokus dari mahasiswa, diantaranya adalah permasalahan stock file batu bara yang dimiliki oleh PT. KBPC yang berada di tengah kota Muara Bungo. Hal ini sebagaimana disampaikan oleh Junaidi selaku DPM STKIP Muhammadiyah Muara Bungo:

“..sebenarnya banyak sekali permasalahan yang ada di Kabupaten Bungo ini, namun ada beberapa hal yang menjadi konsen kita dari mahasiswa Bungo, di antaranya adalah keberadaan Stock File miliknya Syamsudin (PT. KBPC) yang ada di dekat kota Muara Bungo, karena tidak sesuai dengan perundang-undangan dan sangat mengganggu masyarakat sekitar juga membuat keindahan dari kota Bungo menjadi rusak karena pemandangan keluar masuk mobil pengangkut batubara dan keberadaan stock file yang berada di pinggir jalan..." (Junaidi, Wawancara, 15 April 2020)

Beliau melanjutkan:

“..karena itu kita sebagai mahasiswa mencoba mendorong DRPD untuk dapat menyelesaikan permasalahan tersebut, dan Alhamdulillah aspirasi kita didengarkan oleh DPRD Bungo, sehingga pada bulan Februari lalu mereka melakukan Sidak ke Stock File PT. KBPC yang ada di depan Eks Arena MTQ, dan meminta kepada pihak perusahaan agar dapat memindahkan stock file tersebut di luar kota, permintaan tersebut disambut baik oleh perusahaan yang berjanji akan memindahkan lokasi stockfile ke Dusun Sijau..." (Junaidi, Wawancara, 15 April 2020)

Pernyataan tersebut sesuai dengan dokumentasi yang peneliti peroleh sebagaimana terlihat pada gambar berikut:

Peran mahasiswa sebagai Agen of Change dan Social Control adalah perubahan menuju ke arah yang lebih baik dan akan memberikan manfaat serta menjadi pengontrol untuk dirinya sendiri, orang tua, teman-teman, orangorang di sekitarnya dan untuk negara. Untuk diri sendiri manfaat sebagai Agen of Change adalah menjadikan kualitas diri semakin baik, baik kualitas keimanan maupun hubungan sosial. Jadi, mahasiswa itu sebagai agen perubahan untuk dirinya terlebih dahulu baru terhadap yang hal lain, karena suatu perubahan itu tidak akan muncul sebelum kita sendir yang melakukannya. Karena dasar dari semua yang ada di dunia ini adalah manusia itu sendiri misalnya kecanggihan teknologi, itu semua dihasilkan dari potensi dasar yang telah diberikan oleh sang pencipta yaitu berupa akal dan otak yang harus dimanfaatkan sebaikbaiknya. Rasa kebersyukuran adalah satu cara meningktkan kualitas diri seseorang. Sedangkan sebagai social control adalah mahasiswa harus peka terhadap apa saja yang terjadi dalam dirnya terlebih lagi terhadap penyelewangan dan harus segera melakukan koreksi diri.

\section{Pra Aksi Mahasiswa se-Kabupaten Bungo}

Sebelum melakukan aksi tuntutan mahasiswa hal yang pertama dilakukan adalah konsolidasi. konsolidasi merupaka suatu tindakan atau upaya yang dilakukan untuk menyatukan, memperkuat, dan memperteguh hubungan antara dua kelompok atau lebih sehingga terbentuk suatu persatuan yang lebih kuat. Tujuan dilakukannya konsolidasi adalah untuk mempersatukan setiap elemen yang memiliki kesamaan tertentu.

Selanjutnya Debi Krismanto menjelaskan bahwa dalam konsolidasi ada dua hal yang harus diperhatikan,ada yang bersifat subtansi dan bersifat teknis:

1. Subtansi :

a. Target aksi 
Target aksi penting menjadi pokok bahasan saat konsilidasi, karena jangan sampai kita salah sasaran agar suara kita di dengar, jangan sampai kita melakukan aksi namun tidak jelas tujuannya kemana dan pendengarnya tidak tepat sasaran.

b. Isu yang diangkat

Berdasarkan konsilidasi yang kita lakukan bersama terdapat 7 isu utama yang kita angkat yaitu:

1) RKUHP

pasal pasal yang ada didalam RKUHP dinilai mahasiswa masih bermasalah dan perlu dibenahi lagi oleh DPR dan Pemerintah.

2) RUU KPK

didalam uu kpk terdapat pasal yang dapat melemahkan kpk itu sendiri dan ada pasal yang meringkan para koruptor.

3) Isu Lingkungan

mahasiswa menuntut agar pemerintah segera mengusut para elit yang telah merusak alam di indonesia dan harus diadili.

4) RUU Ketengakerjaan

mahasiswa menilai aturan tersebut tidak berpihak kepada pekerja.

5) RUU Pertanahan

mahasiswa menolak ruu pertanahan karna dinilai menghianati terhadap semangat agraria.

6) RUU PKS

dalam demo yang terjadi kemarin mahasiswa meminta agar pemerintahan dan dpr menunda pengesahan ruu penghapusan kekerasan seksual (PKS).

7) Kriminalisasi Aktivis

selama ini banyak kriminalisai yang terjadi pada aktivis di Indonesia dan mahasiswa menuntut agar pemerintahan mengusutnya

2. Teknis

a. Titik kumpul peserta aksi

Kita bersepakat bahwa titik kumpulnya adalah Lapangan Pusparagam Semagor pada pukul 8.00 pagi tanggal 25 September 2019, dimana setiap perwakilan kampus harus membawa minimal 50 orang sebagai peserta aksi.

b. Rute aksi

Rute aksi yang kita lakukan disepakati yakni Lapangan Pusparagam Semagor, kemudian berlanjut ke simpang drum, terakhir di depan gedung DRPD Kabupaten Bungo, dan dalam gedung DRPD Kabupaten Bungo.

c. Alat-alat

Berdasarkan konsilidasi para perwakilan kampus yang ada di Kabupaten Bungo disepakati bahwa alat yang digunakan saat aksi adalah spanduk, toa, bendera, dan karton yang bertuliskan tuntutan mahaasiswa.

d. Susunan dan tugas perangkat aksi:

Hasil konsolidasi disepakati bahwa susunan dan perangkat aksi adalah sebagai berikut: 


$\begin{array}{ll}\text { Koordinator lapangan } & \text { : Ahmad Fadoli } \\ \text { Komdan Lapangan } & \text { : IAI YASNI (Debi Krismanto) } \\ & \text { STIA Setih Setio (Andre G) } \\ & \text { UMB (Een Siska) } \\ & \text { STKIP (Asmara Z) } \\ & \text { Akper Setih Setio (Langgeng A.) } \\ & \text { Akbid Amanah (Indry) } \\ \text { Tim negoisator } & \text { : Para Ketua BEM } \\ \text { Adapun tugasnya sebagai berikut: }\end{array}$

- Korlap (Koordinator Lapangan) adalah pemimpin keseluruhan teknis aksi yang menjalankan rumusan aksi.

- Danlap adalah pemegang komando tertinggi dalam aksi yang bertugas menyampaikan instruksi, memantau dan mengatur jalannya aksi.

- Tim negoisator adalah orang yang bertugas mengkomunikasikan aksi dengan stakeholder terkait seperti polisi, wartawan, dan pihak lain di lapangan. memilih orang yang memiliki kemampuan melobi baik ketika memutuskan memilih tim negoisator .

- Tim Media, tugasnya adalah membuat, memperbanyak dan menyebarkan pernyataan sikap (Press Realease), menghubungi media massa, mengordinasikan wawancara wartawan dengan pimpinan aksi.

- Tim logistic, tugas tim logistik adalah : menyiapkan pengeras suara/ mobil sound/sound system, dan kebutuhan aksi (bendera, air minum dan baliho/pamflet).

- Tim Kesehatan, aksi massa membutuhkan kekuatan fisikdan seringkali mendapat banyak potensi ancaman. Untuk itu diperlukan tim kesehatan untuk mengantisipasi segala kemungkinan yangakan terjadi.

\section{Aksi Gerakan Mahasiswa se-Kabupaten Bungo}

Advokasi berarti suatu cara yang cermat, terencana, dan terorganisir untuk melakukan pembelaan ataupun mendorong suatu perubahan. Jadi tujuan dari advokasi adalah perubahan yang luas terkait kebijakan sehingga masyarakat banyak dapat merasakan manfaatnya. Hanya mengandalkan demonstrasi bukanlah advokasi. Perlu diingat advokasi bukanlah milik advokat ataupun aktivis-aktivis Lembaga Swadaya Masyarakat (LSM). Mahasiswa juga mampu melakukan advokasi.

Manajemen Aksi adalah sebuah sistem pengaturan demonstrasi (aksi massa) yang dilakukan oleh beberapa orang untuk menggalang opini public terhadap suatu masalah yang muncul dan berkembang sehingga diharapkan lahir sebuah perubahan sosial. Menerjunkan massa untuk melakukan aksi ataupun demonstrasi adalah merupakan strategi akhir dalam mengadvokasi setiap kebijakan yang telah disahkan ataupun merugikan banyak kalangan.

Pada tanggal 25 September 2019 Gabungan mahasiswa dari sejumlah kampus di Kabupaten Bungo menggelar aksi advokasi terhadap tuntutan mahasiswa yakni menolak RUU KUHP dan UU KPK. Kehadiran mahasiswa didepan gedung DPRD Kabupaten Bungo meminta anggota DPRD Bungo ikut menandatangani penolakan RUU KUHP dan UU KPK.

Adanya advokasi terhadap tuntutan mahasiswa dengan melakukan demostrasi ke DPRD Kabupaten Bungo, kami meminta agar DPRD Bungo ikut menandatangani penolakan RUU KUHP dan UU KPK, karena kita menilai Sebab, pasal-pasal dalam RKUP dinilai masih bermasalah. Dan Revisi UU KPK dinilai 
membuat lembaga anti korupsi tersebut lemah dalam memberantas aksi para koruptor.

Sebelum berdemonstrasi, mahasiswa dari Universitas Muara Bungo (UMB) Institut Agama Islam (IAI) Yasni Muara Bungo, Akademi Keperawatan (Akper) Setih Setio Muara Bungo, Sekolah Tinggi Ilmu Administrasi (STIA) Setih Setia Muara Bungo, Akademi Kebidanan (Akbid) Muara Bungo, dan Sekolah Tinggi Keguruan dan Ilmu Pendidikan (STKIP) Muhammadiyah Muara Bungo berkumpul di Bundaran Lapangan Puspa Ragam (Semagor) kemudian Mereka melakukan long march menuju gedung DPRD Kabupaten Bungo.

Dan secara bergantian, sejumlah perwakilan BEM Perguruan tinggi di Kabupaten Bungo menyampaikan sejumlah tuntutannya. Dan meminta DPRD Bungo ikut menandatangani penolakan RUU KUHP dan UU KPK. Presiden BEM IAI Yasni Muara Bungo Debi Krismanto dalam orasinya mengatakan pihaknya menolak RUU KUHP dan RUU KPK. Tuntutan mahasiswa kepada DPRD Kabupaten Bungo agar mendukung dan menyampaikan aspirasinya ke DPR RI pusat dengan melakukan penandatanganan terhadap surat pernyataan penolakan terhadap RUU KUHP dan RUU KPK.

Mahasiswa ikut memperjuangkan demokrasi di Indonesia dengan menolak RKUHP yang dianggap mengebiri demokrasi. Salah satunya, melalui pasal yang mengatur soal makar. RKUHP menjelma pasal karet yang jelas bisa digunakan untuk memberangus kebebasan berekspresi dan berpendapat bagi seluruh masyarakat sipil.

Pendapat yang sama juga diungkapkan oleh Mantan Presiden BEM UMB sekaligus Korlap aksi Ahmad Padoli mengatakan, KPK dilemahkan dengan pengesahan revisi UU KPK. Selain itu, kedua UU, yakni KPK dan RKUHP, berdampak langsung terhadap masyarakat luas sehingga harus ditolak. Mahasiswa berharap agar DPRD Bungo memiliki kesepahaman dengan mahasiswa untuk memperjuangkan keberadaan KPK dengan memperkuat legalitas KPK, sehingga KPK menjadi kuat dan tidak dilemahkan oleh oknum yang mengatasnamakan institusi.

Peran mahasiswa sebagai Agen of Change untuk negara kita tercinta yaitu Indonesia. Peran mahasiswa sebagai Agen of Change sangat luas kajiannya, yaitu bisa agen perubahan dalam pendidikan, pembangunan ekonomi, pemberdayaan sosial, pengabdian masyarakat, dan masih banyak lagi. Jika dilihat lagi mahasiswa pada zaman sebelum dan sesudah kemerdekaan sangat jauh perbedaannya, selain sudah berbeda situasinya yang dahulunya melawan bangsa orang lain sedangkan sekarang melawan bangsa sendiri.

Jadi peran mahasiswa disini adalah menanamkan dasar atau pondasi sebelum menjadi Agen of Change yaitu dengan rasa kebersyukuran. Untuk negara mahasiswa sebagai Social Control harus mampu bersikap kritis terhadap apa yang terjadi di pemerintahan, kritis terhadap kebijakan-kebijakan yang dibuat oleh aparat negara yang semula ingin mensejahterakan rakyat malah semakin menyengsarakan rakyat. Upaya kritis itu tidak hanya dengan melakukan aksi demonstrasi yang anarkis atau bakar ban yang membuat jalan macet berkilo-kilo tetapi bisa dilakukan dengan hal yang lebih positif misalnya menulis, bermusyawarah, atau dengan demonstrasi yang tidak memberikan masalah terhadap orang lain.

\section{Pasca Aksi Gerakan Mahasiswa se-Kabupaten Bungo}

Hampir dua jam lebih berorasi, pimpinan DPRD Bungo menerima tuntutan-tuntutan mahasiswa. Para mahasiswa juga mendesak wakil rakyat untuk menandatangani surat pernyataan penolakan terhadap RUU KUHP dan RUU KPK. Untuk sebuah masalah yang merongrong banyak pihak, gerakan 
massa menjadi corong perlawanan. Dalam keadaan genting, aksi massa adalah jalan satu-satunya yang membentuk kesadaran waras rakyat untuk bergerak demi hak, keberpihakan kepada rakyat dan menyatakan mosi tidak percaya kepada DPRD dan elit politik karena tidak mendukung dan berpihak kepada rakyat.

Untuk itu penulis ingin memberikan sebuah alternatif sederhana cara atau upaya untuk mengembalikan itu semua yaitu dengan rasa kebersyukuran sebagai langkah awal mahasiswa sebagai Agen of Change dan Social Control yang baik dan berkualitas. Mengapa rasa kebersyukuran? Karena sekarang ini kita tidak lagi menghadapi musuh dari luar yang berupa fisik tapi kita sedang menghadapi musuh dari dalam, yaitu diri sendiri dan nafsu. Syukur atau rasa kebersyukuran disini maksudnya adalahrasa terimakasih dan selalu merasa cukup terhadap apa yang dimilikinya dan yang tentunya telah didahului dengan usaha yang maksimal. Mahasiswa dengan rasa kebersyukuran pastinya di masa depan akan melahirkan para penerus bangsa yang bertanggung jawab dan tidak akan mudah menerima dan mengambil sesuatu yang tidak harus dimilikinya.

Peran mahasiswa sebagai Agen of Change dan Social Control adalah perubahan menuju ke arah yang lebih baik dan akan memberikan manfaat serta menjadi pengontrol untuk dirinya sendiri, orang tua, teman-teman, orangorang di sekitarnya dan untuk negara. Untuk diri sendiri manfaat sebagai Agen of Change adalah menjadikan kualitas diri semakin baik yaitu dengan rasa kebersyukuran, baik kualitas keimanan maupun hubungan sosial. Jadi, mahasiswa itu sebagai agen perubahan untuk dirinya terlebih dahulu baru terhadap yang hal lain, karena suatu perubahan itu tidak akan muncul sebelum kita sendir yang melakukannya. Karena dasar dari semua yang ada di dunia ini adalah manusia itu sendiri misalnya kecanggihan teknologi, itu semua dihasilkan dari potensi dasar yang telah diberikan oleh sang pencipta yaitu berupa akal dan otak yang harus dimanfaatkan sebaik-baiknya. Rasa kebersyukuran adalah satu cara meningktkan kualitas diri seseorang. Sedangkan sebagai social control adalah mahasiswa harus peka terhadap apa saja yang terjadi dalam dirnya terlebih lagi terhadap penyelewangan dan harus segera melakukan koreksi diri . Adanya kesadaran dari mahasiswa untuk mendorong perubahan yang terjadi di masyarakat yang dimulai dari lingkungan keluarga, untuk itu dibutuhkan rasa empati pada diri mahasiswa agar benar-benar meresapi apa yang terjadi di lingkungan sekitar.

\section{Hambatan dalam pergerakan mahasiswa sebagai agen perubahan sosial di Kabupaten Bungo pada advokasi tuntutan mahasiswa}

Berdasarkan hasil wawancara dengan beberapa informan diketahui hambatan dalam pergerakan mahasiswa sebagai agen perubahan sosial di Kabupaten Bungo pada advokasi tuntutan mahasiswa:

1. Kurangnya rasa kesadaran mahasiswa itu sendiri

Pertama, dari faktor Internal atau dalam diri mahasiswa itu sendiri adalah kurangnya rasa kesadaran yang dimiliki untuk melakukan perubahan pada diri sendirinya dahulu. Pentingnya kesadaran diri dari mahasiswa itu sendiri agar peka terhadap permasalahan di lingkunganya, sehingga mampu peduli terhadap apa yang terjadi di sekitarnya yang pada akhirnya akan menimbulkan rasa empati dari mahasiswa tersebut sehingga mampu memperjuangkan keadilan dan kebenaran bagi semua masyarakat.

2. Globaliasasi dan Modernisasi

Yang kedua adalah faktor eksternal yaitu adanya globaliasasi dan modernisasi yaitu kemajuan teknologi, sifat konsumtif, informasi 
yang tidak dapat di saring, dampak negatif lainnya. Dengan adanya kemajuan teknologi ini kemudahan mengakses internet menjadi sarana terbuka lebar untuk membuka situs-situs yang tidak seharusnya menjadi konsumsi umum. Rasa empati disi sangatlah penting untuk menghindari hal-hal tersebut. Mahasiswa dengan rasa empati akan selalu memikirkan apa yang telah ia dapatkan dan tidak sempat melakukan hal-hal yang tidak bermanfaat baginya.

Jadi, marilah kita sebagai penerus dan harapan bangsa di masa depan dapat menjadikan rasa kebersyukuran ini sebagai dasar dan pondasi dalam pengoptimalan peran mahasiswa sebagai Agen of Change dan Social Control yang baik dan berkualitas. Dan bayangkan apa yang terjadi jika semua pemerintah dan petinggi negara memiliki dasar yang baik dalam membangun bangsa? Tidak akan ada lagi masyarakat yang hidup dengan kemiskinan, memakan nasi basi yang dikeringkan dan banyak lagi hal-hal miris yang diakibatkan oleh para pemimpin negara yang tega mengambil hak yang bukan miliknya.

Advokasi selamanya menyangkut perubahan yang mengubah beberapa kebijakan, regulasi, dan cara badan-badan perwakilan melakukan kebijakan. Dalam melakukan perubahan kebijakan pun tidak semudah yang kita bayangkan; ada beberapa lapisan yang harus kita lewati untuk melakukan perubahan tersebut.

3. Belum terbentuknya Forum Komunikasi BEM se-Kabupaten Bungo

Belum adanya forum komunikasi antar BEM se-Kabupaten Bungo menjadi salah satu faktor penghambat pergerakan mahasiswa di Kabupaten Bungo, hal ini dikarenakan forum komunikasi merupakan suatu wadah yang dapat melakukan konsilidasi dalam penyatuan pemahaman dan persepsi mahasiswa terhadap isu-isu yang terjadi saat ini. Forum komunikasi BEM sangat dibutuhkan dalam organisasi kemahasiswaan di Kabupaten Bungo, dengan adanya forum tersebut dapat menjalin komunikasi yang difokuskan dalam penyelesaian permasalahan yang ada melalui gerakan mahasiswa sebagai agen perubahan.

\section{Penutup}

Kesimpulan dari penelitian ini adalah 1) Gerakan mahasiswa sebagai agen perubahan sosial di Kabupaten Bungo dalam advokasi tuntutan mahasiswa dilakukan dengan a. Pemetaan Isu Gerakan Mahasiswa se-Kabupaten Bungo. Isu adalah langkah awal sebelum melakukan aksi atau propaganda, dan juga dapat dikatakan bahwa kehadiran isu harus menjadi syarat utama dalam pengadvokasian sebuah peristiwa; b.Pra Aksi Gerakan Mahasiswa se-Kabupaten Bungo. Sebelum melakukan aksi tuntutan mahasiswa hal yang pertama dilakukan adalah konsolidasi. Konsolidasi ada dua hal yang harus diperhatikan, ada yang bersifat subtansi dan bersifat teknis; c. Aksi Gerakan Mahasiswa se-Kabupaten Bungo Manajemen Aksi adalah sebuah sistem pengaturan demonstrasi (aksi massa) yang dilakukan oleh beberapa orang untuk menggalang opini public terhadap suatu masalah yang muncul dan berkembang sehingga diharapkan lahir sebuah perubahan sosial; d. Pasca Aksi Gerakan Mahasiswa se-Kabupaten Bungo. Pasca aksi adalah hasil ataupun output dari kegiatan aksi yang telah dilakukan oleh mahasiswa dalam tuntutannya, baik dalam bentuk pernyataan secara lisan maupun dalam bentuk tertulis. 2) Beberapa hambatan dalam pergerakan mahasiswa sebagai agen perubahan sosial di Kabupaten Bungo pada advokasi tuntutan mahasiswa yaitu a. kurangnya rasa kesadaran mahasiswa itu sendiri; b. Globalisasi 
dan Modernisasi; c. Belum terbentuknya forum komunikasi antar BEM seKabupaten Bungo.

Selanjurnya, terdapat beberapa saran yaitu 1) Diharapkan mahasiswa dari berbagai perguruan tinggi yang ada di Kabupaten Bungo untuk membentuk Forum Komunikasi BEM se-Kabupaten Bungo agar mudah melakukan konsolidasi saat akan ada aksi tuntutan mahasiswa. 2)Perlu adanya dukungan dari seluruh elemen kampus untuk mendukung dan mendorong mahasiswa sebagai agen perubahan.

\section{Referensi}

Anwar, Syaiful. (2013). Agen Perubahan (Agent Of Change), Jurnal (http://www.bppk.kemenkeu.go.id), diakses 12 Februari 2020.

Azumardi Azra. (2005). Demokrasi, Hak Asasi Manusia, dan Masyarakat Madani (Jakarta: Prenada Media, 2005).

Budiman, Fikri. (2016). Agen Perubahan Dan Perannya dalam Divusi Inovasi,

Cahyono, H. (2019). Peran Mahasiswa di Masyarakat. De Banten-Bode: Jurnal Pengabdian Kepada Masyarakat (PKM) Setiabudhi, 1(1), 32-41.

Darmawan Triwibowo. (2006). GERAKAN SOSIAL. Jakarta: Pustaka LP3ES Indonesia. hlm. XV. George Sorensen. (2003). Demokrasi dan Demokratisasi. Pustaka Pelajar.

Istichomaharani, I. S., \& Habibah, S. S. (2016). Mewujudkan peran mahasiswa sebagai agent of change, social control, dan iron stock. Prosiding Seminar Nasioanal Dan Call For Paper Ke, 2, $1-6$.

Kurniawati, R., \& Leonardi, T. (2013). Hubungan antara metakognisi dengan prestasi akademik pada mahasiswa fakultas psikologi universitas airlangga yang aktif berorganisasi di organisasi mahasiswa tingkat fakultas. Jurnal Psikologi Pendidikan Dan Perkembangan, 2(01), 1-6.

Nasution, Zulkarnain. (2016). Pola Agen Perubahan Dalam Pemberdayaan Masyarakat Melalui Jaringan Pendidikan Nonformal dan Informal, (Online), (http://library.um.ac .id/index.php/Rubrik/pola-agen-perubahan-dalam- pemberdayaan-masyarakat-melaluijaringan-pendidikan-nonformal-dan-informal.html), diakses 12 September 2017.

Rafael Raga Maran. (2007). Pengantar SOSIOLOGI POLITIK. Jakarta: PT Rineka Cipta.

Ritu R. Sharma. (2004). Pengantar Advokasi: Panduan Latihan, Jakarta:Yayasan Obor.

Rivai, Veithzal dan Mulyadi, Deddy. (2009). Kepemimpinan dan Perilaku Organisasi. Jakarta: PT Raja Grafindo Persada.

Siallagan, "Fungsi dan Peranan Mahasiswa", diakses dari www.academia.edu. Pada tanggal 21 Desember 2019 pukul 21:58.

Supriyanto, A. (2009). Manajemen Perunahan: Bahan Ajar Berbasis Benchmarking. Malang: Fakultas Ilmu Pendidikan Universitas Negeri Malang.

Syahrial Syarbaini.(2013). Dasar-dasar Sosiologi. Yogyakarta: Graha Ilmu.

Ubedilah Badrun. (2016). Sistem Politik Indonesia. Jakarta:Bumi Aksara.

Wahjosumidjo. (2002). Kepemimpinan Kepala Sekolah Tinjauan Teoritik dan Permasalahannya. Jakarta: PT. Raja Grafindo Persada.

Wibowo. (2006). Manajemen Perubahan. Jakarta: PT Raja Grafindo Persada.

Winardi. (2005). Manajemen Perubahan. Jakarta: Kencana.

Zayinatul Mustafidah, "Gerakan Mahasiswa Dan Kebijakan NKK/BKK TAHUN 1978-1983” 